\title{
PENGARUH KOMPENSASI DAN LINGKUNGAN KERJA TERHADAP KINERJA MELALUI MOTIVASI KERJA PADA PT. PETROIL INDONESIA
}

Asrun Tonga ${ }^{1}$, Nurul Huda ${ }^{2}$

Nurul.huda@yarsi.ac.id

Program Magister Manajemen Sekolah Pascasarjana Universitas YARSI

Received: 15 Maret 2018

Final Acepted: 14 Mei 2018

Published Online: Juni 2018

Keywords:

Compensation, Work Environment, Performance, Motivation, SEM

Corresponding Authors:

* Nurul Huda

\begin{abstract}
This study aims to analyze the factors that affect the performance of PT. Petroil Indonesia. The research focus used is the compensation variable and work environment variable on performance through work motivation. In order to know how far the influence of variables of compensation and work environment variables affect the performance factors through employee motivation, the researcher in this case has done the research with the sampling model used in this research is non probability sampling with slovin method so that the obtained sample as much as 248 of respondents from 650 respondents. Instrument calibration is done to test the validity of grain and reliability coefficient. Grain validity was calculated by using correlation product moment coefficients and reliability was calculated using the coefficient of cronbach's alpha.The hypothesis used in this research is using Structural Equation Modeling (SEM) analysis technique. From the results of the study showed all hypothesis proposed in this research accepted. This means that there is a significant influence between compensation, work environment to work motivation and performance.
\end{abstract}

Copyright JEBA 2018., All rights reserved

\begin{abstract}
ABSTRAK
Penelitian ini bertujuan untuk menganalisis faktor-faktor yang berpengaruh terhadap kinerja PT. Petroil Indonesia. Fokus penelitian yang digunakan adalah variabel kompensasi dan variabel lingkungan kerja terhadap kinerja melalui motivasi kerja. Guna untuk mengetahui sejauh mana pengaruh variable konpensasi dan variabel lingkungan kerja memperngaruhi faktor kinerja melalui motivasi kerja terhadap karyawan, maka peneliti dalam hal ini telah melakukan penelitian dengan model pengambilan sampel yang digunakan dalam penelitian ini yaitu non probability sampling dengan metode slovin sehingga diperoleh sampel sebanyak 248 orang responden dari 650 orang responden. Kalibrasi instrument dilakukan untuk menguji validitas butir dan koefisien reliabilitas. Validitas butir dihitung dengan menggunakan koefisien correlations product moment dan reliabilitas dihitung dengan menggunakan koefisien cronbach's alfa.Hipotesis yang digunakan dalam penelitian ini menggunakan teknik analisis Structural Equation Modeling (SEM). Dari hasil penelitian menunjukkan seluruh hipotesis yang diajukan dalam penelitian ini diterima. Artinya terdapat pengaruh signifikan antara kompensasi, lingkungan kerja terhadap motivasi kerja dan kinerja.

Kata Kunci: Kompensasi, Lingkungan Kerja, Kinerja, Motivasi, SEM
\end{abstract}




\section{PENDAHULUAN}

Stabilitas dan pengalokasian Sumber Daya Manusia (SDM) pada perusahaan PT. Petroil Indonesia memegang peranan penting dalam pengelolaan organisasi perusahaan, pengelolaan tenaga kerja terampil memiliki peran yang besar dan menentukan serta di butuhkan untuk menjalankan roda aktivitas perusahaan. Potensi setiap sumber daya manusia yang ada dalam Perusahaan hanya dapat bermanfaat apabila di direncanakan dan kelolah secara baik, sehingga dengan demikian dapat berdampak kepada pencapaian kinerja perusahaan yang efektif dan optimal.

Optimalisasi kinerja karyawan dilakukan dengan berbagai pendekatan antara lain penyelenggaraan pendidikan, pelatihan dan pemberian kompensasi yang layak, atau menciptakan lingkungan kerja yang kondusif melalui pemberian motivasi. Melalui proses-proses tersebut, maka karyawan diharapkan lebih memaksimalkan kinerja dan tanggung jawab atas pekerjaannya karena para karyawan telah terbekali dengan keterampilan yang diperolehnya yang berkaitan dengan implementasi dan tanggung jawab kerja. Pemberian kompensasi yang layak dan motivasi serta lingkungan kerja yang baik pada dasarnya adalah merupakan hak para karyawan. Disamping itu pihak perusahaan mempunyai kewajiban untuk mendukung kontribusi para karyawannya dalam rangka mencapai tujuan yang telah ditentukan. Demikian halnya dengan apakah yang telah dilakukan oleh PT. Petroil Indonesia dalam rangkah untuk memacu kinerja karyawannya.

Lingkungan kerja yang menyenangkan bagi karyawan yang ada di tempat bekerja membawa dampak positif bagi karyawan, sehingga kinerja karyawan dapat meningkat. Lingkungan kerja adalah semua keadaan tempat kerja yang dapat mempengaruhi karyawan baik secara langsung maupun tidak langsung selain itu lingkungan kerja merupakan suatu komunitas manusia berkumpul dalam suatu keberagaman serta dalam situasi dan kondisi yang berubah-ubah yang dapat mempengaruhi kinerja karyawan sehingga produk yang dihasilkan kurang efektif dan hal ini berarti produktivitas karyawan semakin menurun.

Kondisi dan keadaan lingkungan kerja perusahaan PT. Petroil Indonesia yang layak dan adil adalah menjadi pedoman dan landasan dalam penerapan kinerja yang maksinal dan pemberian jasa kompensasi bagi para karyawan dalam rangka untuk memacu pencapaian tujuan perusahaan sesuai visinya yakni "Ramah Lingkungan dan 
Terdepan', Lingkungan kerja dapat dijadikan sebagai hal yang penting bagi para karyawan dimana setiap karyawan memiliki hak atas hal tersebut. Lingkungan kerja merupakan salah satu hal yang sensitif di dalam dunia kerja karena dapat membuat para karyawan merasa puas bekerja di perusahaan yang berdampak pada karyawan dalam meningkatkan produktivitas kerja karyawan.

Motivasi juga dapat dijadikan sebagai sarana penggerak dalam meningkatkan kinerja karyawan. Dimana melalui pemberian motivasi tersebut, maka para karyawan diharapkan dapat bekerjasama dengan baik dan bekerja secara efektif dengan segala upaya untuk mencapai kepuasan dalam bekerja, sehingga berdampak pada produktivitas kerja karyawan yang lebih baik dari yang sebelumnya. Motivasi juga sangat sensitif dalam pencapaian tujuan perusahaan karena motivasi merupakan dorongan yang diberikan perusahaan kepada karyawannya agar mereka selalu bersemangat dalam bekerja sehingga tujuan perusahaan dapat tercapai. Tanpa motivasi, seorang karyawan tidak dapat memenuhi apa yang menjadi motifnya dalam bekerja sehingga target kerjanya tidak akan terpenuhi, karena motivasi adalah merupakan dorongan dalam diri seseorang yang berhubungan dengan tingkat, arah, dan presistensi konsistensi usaha yang dilakukan seseorang dalam bekerja.

Pemberian kompensasi yang layak kepada karyawan sebagai pengakuan perusahaan terhadap kinerja karyawan adalah menjadi kewajiban perusahaan untuk memenuhi kebutuhan hidup karyawan, selain dari itu penciptaan kondisi lingkungan kerja yang kondusif dan nyaman mendorong motivasi dan kinerja karyawan untuk menyelesaikan tanggung jawab yang diberikan sesuai waktu yang ditentukan.

Berdasarkan uraian di atas, maka tujuan penelitian yang akan dibahas adalah sebagai berikut :

1. Menganalisis pengaruh kompensasi terhadap kinerja pada PT. Petroil Indonesia.

2. Menganalisis pengaruh kompensasi terhadap motivasi kerja pada PT. Petroil Indonesia.

3. Menganalisis pengaruh lingkungan kerja terhadap kinerja pada PT. Petroil Indonesia.

4. Menganalisis pengaruh lingkungan kerja terhadap motivasi kerja pada PT. Petroil Indonesia.

5. Menganalisis pengaruh motivasi terhadap kinerja pada PT. Petroil Indonesia. 


\section{KAJIAN TEORI}

\section{Hakikat Dasar Kompensasi}

Menurut Sofyandi (2008) mendefinisikan tentang kompensasi merupakan suatu bentuk biaya yang harus dikeluarkan oleh perusahaan dengan harapan bahwa perusahaan akan memperoleh imbalan dalam bentuk prestasi kerja dari karyawan.

Hasibuan (2014) menjelaskan tujuan pemberian kompensasi sebagai ikatan kerjasama, kepuasan kerja, pengadaan efektif, motivasi, stabilitas karyawan, disiplin, serta pengaruh serikat buruh dan pemerintah.

Hasibuan (2014) menjelaskan bahwa kompensasi dibedakan menjadi dua bentuk: (1) Kompensasi dalam bentuk Finansial, kompensasi finansial dibagi menjadi dua bagian, yaitu kompensasi finansial yang dibayarkan secara langsung seperti gaji, upah, komisi dan bonus. Kompensasi finansial yang diberikan secara tidak langsung, seperti tunjangan kesehatan, tunjangan pensiun, tunjangan hari raya, tunjangan perumahan, tunjangan pendidikan dan lain sebagainya. (2) Kompensasi dalam bentuk non finansial, kompensasi dalam bentuk non finansial dibagi menjadi dua macam, yakni yang berhubungan dengan pekerjaan dan yang berhubungan dengan lingkungan kerja. Yang berhubungan dengan pekerjaan, misalnya kebijakan perusahaan yang sehat, pekerjaan yang sesuai (menarik, menantang), peluang untuk dipromosikan, mendapat jabatan sebagai simbol status. Sedangkan kompensasi non finansial yang berhubungan dengan lingkungan kerja, seperti ditempatkan dilingkungan kerja yang kondusif, fasilitas kerja yang baik dan lain sebagainya.

\section{Lingkungan Kerja}

Menurut Sedarmayanti (2012) Lingkungan kerja adalah keseluruhan alat perkakas dan bahan yang dihadapi lingkungan sekitarnya dimana seseorang bekerja, metode kerjanya, serta pengaturan kerjanya baik sebagai perseorangan maupun sebagai kelompok.

Menurut Sedarmayanti (2012) menyatakan bahwa secara garis besar, jenis lingkungan kerja terbagi menjadi dua:

1. Lingkungan kerja fisik adalah semua keadaan berbentuk fisik yang terdapat di sekitar tempat kerja yang dapat mempengaruhi karyawan baik secara langsung 
maupun scara tidak langsung. Lingkungan kerja fisik dapat dibagi dalam dua kategori, yakni :

a) Lingkungan yang langsung berhubungan dengan karyawan. Seperti: pusat kerja, kursi, meja dan sebagainya.

b) Lingkungan perantara atau lingkungan umum dapat juga disebut lingkungan kerja yang mempengaruhi kondisi manusia, misalnya: temperatur, kelembaban, sirkulasi udara, pencahayaan, kebisingan, getaran mekanis, bau tidak sedap, warna, dan lain-lain. Untuk dapat memperkecil pengaruh lingkungan fisik terhadap karyawan, maka langkah pertama adalah harus mempelajari manusia, baik mengenai fisik dan tingkah lakunya maupun mengenai fisiknya, kemudian digunakan sebagai dasar memikirkan lingkungan fisik yang sesuai.

2. Lingkungan Kerja Non Fisik, adalah semua keadaan yang terjadi yang berkaitan dengan hubungan kerja, baik hubungan dengan atasan maupun hubungan sesama rekan kerja, ataupun hubungan dengan bawahan”. Lingkungan non fisik ini juga merupakan kelompok lingkungan kerja yang tidak bisa diabaikan.

Schultz dan Schultz (2010:405) Lingkungan atau kondisi kerja adalah semua aspek fisik kerja, psikologis kerja dan peraturan kerja yang dapat mempengaruhi kepuasan kerja dan produktivitas kerja.

\section{Motivasi Kerja}

Menurut Luthans (2011) menjelaskan bahwa :"Motivation is a psychological process through which unsatisfied wants or needs lead to drives that are aimed at goals or incentives". Motivasi merupakan sebuah proses psikologi dimana rasa ketidakpuasan pada kebutuhan ataupun keinginan yang ada sehingga berusaha untuk mencapai suatu tujuan yang diinginkan. Proses tersebut dapat digambarkan sebagai berikut :

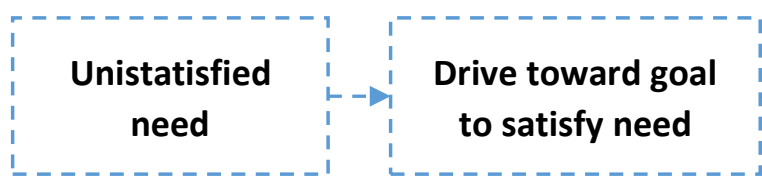

\section{Attainment of foal}

(need satisfaction)

Gambar 1

Proses Motivasi 
Menurut Samsudin (2010:281) mengemukakan bahwa motivasi adalah proses mempengaruhi atau mendorong dari luar terhadap seseorang atau kelompok kerja agar mereka mau melaksanakan sesuatu yang telah ditetapkan. Sedangkan menurut Liang Gie dalam Samsudin menyatakan bahwa motivasi adalah pekerjaan yang dilakukan oleh manajer dalam memberikan inspirasi, semangat dan dorongan kepada orang lain, dalam hal ini karyawannya, untuk mengambil tindakan-tindakan tertentu.

\section{Kinerja}

Menurut Sutrisno (2010) menyimpulkan kinerja sebagai hasil kerja dilihat dari aspek kualitas, kuantitas, waktu kerja, dan kerja sama untuk mencai tujuan yang sudah di tetapkan oleh organisasi.

Menurut Rivai (2013), kinerja merupakan suatu istilah secara umum yang digunakan sebagian atau seluruh tindakan atau aktivitas dari suatu organisasi pada suatu periode dengan suatu referensi pada sejumlah standar seperti biaya masa lalu yang diproyeksikan dengan dasar efisiensi, pertanggungjawaban atau akuntabilitas manajemen dan semacamnya.

Menurut Wirawan (2015) merupakan singkatan dari kinetika energi kerja yaitu energi manusia jika dikinetikkan atau dipekerjakan akan menghasilkan keluaran kerja.

\section{Hasil Penelitian Yang Relevan}

Beberapa hasil penelitian yang relevan dengan penelitian ini yaitu :

Tabel 1 Penelitian Terdahulu

\begin{tabular}{|c|c|c|c|c|}
\hline No. & Peneliti & Judul & Variabel Penelitian & Hasil Penelitian \\
\hline 1 & $\begin{array}{l}\text { Pane, at.all } \\
(2009)\end{array}$ & $\begin{array}{l}\text { Pengaruh Budaya } \\
\text { Organisasi, } \\
\text { Kepemimpinan } \\
\text { Transformasional, } \\
\text { dan Kompensasi } \\
\text { Terhadap Kinerja } \\
\text { Karyawan } \quad \text { Studi } \\
\text { pada Kantor } \\
\text { Telkom Divre IV di } \\
\text { Semarang) }\end{array}$ & $\begin{array}{l}\text { - Budaya Organisasi } \\
\text { - Kepemimpinan } \\
\text { Transformasional } \\
\text { - Kompensasi } \\
\text { - Kinerja Karyawan }\end{array}$ & $\begin{array}{l}\text { Hasil penelitian menunjukkan } \\
\text { bahwa kepemimpinan } \\
\text { transformasional dan } \\
\text { kompensasi berpengaruh positif } \\
\text { terhadap kinerja pegawai, } \\
\text { namun budaya organisasi tidak } \\
\text { berpengaruh terhadap kinerja } \\
\text { pegawai. Hal ini menunjukkan } \\
\text { bahwa The Telkom Way } 135 \\
\text { yang dibuat sejak tahun } 2003\end{array}$ \\
\hline
\end{tabular}




\begin{tabular}{|c|c|c|c|c|}
\hline No. & Peneliti & Judul & Variabel Penelitian & Hasil Penelitian \\
\hline & & & & $\begin{array}{l}\text { tidak berpengaruh terhadap } \\
\text { kinerja pegawai karena } \\
\text { sebelumnya Telkom telah } \\
\text { mempunyai budaya organisasi } \\
\text { yang kuat. Selanjutnya, hasil } \\
\text { menunjukkan bahwa } \\
\text { kepemimpinan transformasional } \\
\text { mempunyai pengaruh yang } \\
\text { lebih kuat terhadap kinerja } \\
\text { pegawai daripada kompensasi. }\end{array}$ \\
\hline 2 & $\begin{array}{l}\text { Juliningrum, } \\
\text { at.all, (2011) }\end{array}$ & $\begin{array}{l}\text { Pengaruh } \\
\text { Kompensasi, } \\
\text { Budaya Organisasi, } \\
\text { terhadap Motivasi } \\
\text { Kerja dan Kinerja } \\
\text { Pegawai PTIIK UB }\end{array}$ & $\begin{array}{l}\text { - Kompensasi } \\
\text { - Budaya Organisasi } \\
\text { - Motivasi Kerja } \\
\text { - Kinerja Pegawai }\end{array}$ & $\begin{array}{l}\text { Dari hasil penelitian dapat } \\
\text { disimpulkan bahwa Kompensasi } \\
\text { belum mampu memberikan } \\
\text { kontribusi terhadap motivasi } \\
\text { kerja dan kinerja. Akan tetapi } \\
\text { budaya organisasi seperti } \\
\text { penerapan tentang aturan-aturan } \\
\text { yang diberikan pegawai } \\
\text { berpengaruh terhadap motivasi } \\
\text { kerja pegawai PTIIK UB } \\
\text { sehingga akan memberikan } \\
\text { kontribusi positif terhadap } \\
\text { kinerja pegawai. }\end{array}$ \\
\hline 3 & $\begin{array}{l}\text { Pontoh } \\
\text { (2013) }\end{array}$ & \begin{tabular}{lr}
\multicolumn{2}{l}{ Pengaruh } \\
Kompensasi \\
Beban dan \\
Terhadap & Kepuasan \\
Kerja & Dan \\
Dampaknya Pada \\
Kinerja Pegawai \\
Pada Padan \\
Perencanaan \\
Pembangunan \\
Daerah Propinsi \\
\multicolumn{2}{l}{ Sulawesi Tengah }
\end{tabular} & $\begin{array}{l}\text { - Kompensasi } \\
\text { - Beban Kerja } \\
\text { - Kepuasan Kerja } \\
\text { - Kinerja Pegawai }\end{array}$ & $\begin{array}{l}\text { Hasil penelitian menunjukkan } \\
\text { bahwa: (1) kompensasi } \\
\text { berpengaruh signifikan terhadap } \\
\text { kepuasan kerja; (2) beban kerja } \\
\text { berpengaruh signifikan terhadap } \\
\text { kepuasan kerja; (3) Kepuasan } \\
\text { kerja berpengaruh signifikan } \\
\text { terhadap kinerja karyawan; (4) } \\
\text { Kompensasi memiliki pengaruh } \\
\text { yang signifikan terhadap kinerja } \\
\text { karyawan dan (5) beban kerja } \\
\text { berpengaruh signifikan terhadap } \\
\text { kinerja pegawai Pemprov } \\
\text { Sulawesi Tengah. }\end{array}$ \\
\hline 4 & $\begin{array}{l}\text { Sahilmi, } \\
\text { at.all, (2014) }\end{array}$ & $\begin{array}{lr}\text { Pengaruh } \\
\text { Penggunaan } & \text { Sistem } \\
\text { Informasi } & \text { dan } \\
\text { Lingkungan } & \text { Kerja } \\
\text { Terhadap } & \text { Motivasi } \\
\text { Kerja } & \text { Serta } \\
\text { Dampaknya } & \text { Pada } \\
\text { Kinerja } & \text { Pegawai }\end{array}$ & $\begin{array}{l}\text { - Penggunaan } \\
\text { Sistem Informasi } \\
\text { - Lingkungan Kerja } \\
\text { Terhadap Motivasi } \\
\text { Kerja } \\
\text { - Kinerja Pegawai }\end{array}$ & $\begin{array}{l}\text { Dari hasil penelitian diperoleh } \\
\text { bahwa penggunaan sistem } \\
\text { informasi berpengaruh signifkan } \\
\text { terhadap motivasi kerja sebesar } \\
0.226 \text {, lingkungan kerja } \\
\text { berpengaruh signifikan terhadap } \\
\text { motivasi kerja sebesar } 0.111 \\
\text { dan motivasi kerja berpengaruh }\end{array}$ \\
\hline
\end{tabular}




\begin{tabular}{|c|c|c|c|c|}
\hline No. & Peneliti & Judul & Variabel Penelitian & Hasil Penelitian \\
\hline & & $\begin{array}{l}\text { Kantor } \\
\text { Kementerian } \\
\text { Agama Kabupaten } \\
\text { Aceh Barat Daya }\end{array}$ & & $\begin{array}{lrr}\text { signifikan } & \text { terhadap } & \text { kinerja } \\
\text { pegawai } & \text { sebesar } 0.193 . & \text { Secara } \\
\text { langsung } & \text { penggunaan } & \text { sistem } \\
\text { informasi } & \text { dapat mempengaruhi } \\
\text { secara } & \text { signifikan } & \text { kinerja } \\
\text { pegawai } & \text { sebesar } & 0.263 \text {, } \\
\text { lingkungan } & \text { kerja } & \text { secara } \\
\text { langsung tidak } & \text { signifikan } \\
\text { berpengaruh terhadap } & \text { kinerja } \\
\text { pegawai dan secara } & \text { tidak } \\
\text { langsung penggunaan } & \text { sistem } \\
\text { informasi berpengaruh terhadap } \\
\text { kinerja pegawai } & \text { melalui } \\
\text { motivasi kerja sebesar } & 0.209 \\
\text { sedangkan pengaruh } & \text { tidak } \\
\text { langsung lingkungan } & \text { kerja } \\
\text { terhadap } & \text { kinerja } & \text { pegawai } \\
\text { melalui motivasi kerja } & \text { sebesar } \\
\text { 0.146. Variabel yang } & \text { paling } \\
\text { besar pengaruhnya } & \text { terhadap } \\
\text { kinerja pegawai } & \text { Kantor } \\
\text { Kementerian Agama Kabupaten } \\
\text { Aceh Barat Daya } & \text { adalah } \\
\text { variabel penggunaan } & \text { sistem } \\
\text { informasi } & \text { sedangkan } & \text { variabel } \\
\text { yang paling besar pengaruhnya } \\
\text { terhadap motivasi kerja juga } \\
\text { variabel penggunaan } & \text { sistem } \\
\text { informasi. Dalam meningkatkan } \\
\text { motivasi kerja pegawai Kantor } \\
\text { Kementerian Agama Kabupaten } \\
\text { Aceh Barat Daya perlu } \\
\text { memperhatikan kembali sistem } \\
\text { informasi dan lingkungan kerja }\end{array}$ \\
\hline 5 & $\begin{array}{l}\text { Pulungan } \\
\text { at.all (2015) }\end{array}$ & $\begin{array}{l}\text { Pengaruh Kepuasan } \\
\text { Kerja, Kompensasi } \\
\text { dan Pelatihan } \\
\text { Terhadap Motivasi } \\
\text { Serta Dampaknya } \\
\text { Pada Kinerja } \\
\text { Karyawan Kantor } \\
\text { Pt. (Persero) } \\
\text { Telekomunikasi } \\
\text { Indonesia, Tbk } \\
\text { Wilayah Aceh }\end{array}$ & $\begin{array}{l}\text { - Kepuasan Kerja } \\
\text { - Kompensasi } \\
\text { - Pelatihan } \\
\text { - Motivasi } \\
\text { - Kinerja Karyawan }\end{array}$ & $\begin{array}{l}\text { Penelitian menemukan bahwa } \\
\text { kepuasan kerja, kompensasi dan } \\
\text { pelatihan berpengaruh secara } \\
\text { langsung terhadap motivasi } \\
\text { kerja dan kinerja karyawan. } \\
\text { pengaruh langsung } \text { (direct } \\
\text { effect) kepuasan } r \text { kerja, } \\
\text { kompensasi dan pelatihan } \\
\text { terhadap motivasi kerja } \\
\text { karyawan } \\
\text { sebesar } 10,05 \text { persen, } 13,32\end{array}$ \\
\hline
\end{tabular}




\begin{tabular}{|c|c|c|c|c|}
\hline No. & Peneliti & Judul & Variabel Penelitian & Hasil Penelitian \\
\hline & & & & $\begin{array}{l}\text { persen, dan sebesar } 10,06 \\
\text { persen. Selanjutnya pengaruh } \\
\text { langsung (direct effect) } \\
\text { kepuasan kerja, kompensasi dan } \\
\text { pelatihan terhadap kinerja } \\
\text { karyawan masing-masing } \\
\text { sebesar 5,76 persen, 10,30 } \\
\text { persen dan sebesar 5,24 persen. } \\
\text { Pengaruh langsung (direct } \\
\text { effect) motivasi kerja terhadap } \\
\text { kinerja karyawan sebesar } 39,19 \\
\text { persen lebih besar bila } \\
\text { dibandingkan dengan pengaruh } \\
\text { tiga variabel lainnya. } \\
\text { selanjutnya pengaruh tidak } \\
\text { langsung (indirect effect) } \\
\text { kepuasan kerja, kompensasi dan } \\
\text { pelatihan terhadap kinerja } \\
\text { karyawan lebih besar bila } \\
\text { dibandingkan dengan pengaruh } \\
\text { langsung (direct effect) ketiga } \\
\text { variabel tersebut terhadap } \\
\text { kinerja karyawan. }\end{array}$ \\
\hline 6 & Ardi, (2016) & $\begin{array}{lr}\text { Pengaruh } & \text { Disiplin } \\
\text { Kerja, } & \text { Promosi } \\
\text { Jabatan } & \text { dan } \\
\text { Kompensasi } \\
\text { Terhadap } & \text { Kinerja } \\
\text { Pegawai r pada } \\
\text { Dinas Kebudayaan } \\
\text { Pariwisata Pemuda } \\
\text { dan Olahraga } \\
\text { Kabupaten } \\
\text { Rembang }\end{array}$ & $\begin{array}{l}\text { - Disiplin Kerja } \\
\text { - Promosi Jabatan } \\
\text { - Kompensasi } \\
\text { - Kinerja Pegawai }\end{array}$ & $\begin{array}{l}\text { Hasil pengujian menunjukkan } \\
\text { bahwa peningkatan disiplin } \\
\text { kerja, promosi jabatan dan } \\
\text { kompensasi akan diikuti } \\
\text { peningkatan kinerja karyawan, } \\
\text { demikian pula sebaliknya. } \\
\text { Kasus ini menunjukkan bahwa } \\
\text { untuk meningkatkan kinerja } \\
\text { karyawan diperlukan adanya } \\
\text { pemerataan disiplin kerja, } \\
\text { peluang dalam promosi jabatan } \\
\text { dan pemberian kompensasi } \\
\text { yang sesuai dengan keinginan } \\
\text { karyawan. }\end{array}$ \\
\hline 7 & Raja, (2017) & $\begin{array}{l}\text { Hubungan } \\
\text { Motivasi, } \\
\text { Lingkungan Kerja, } \\
\text { Kepemimpinan, } \\
\text { Disiplin Kerja, dan } \\
\text { Kinerja Karyawan } \\
\text { PT Asiana } \\
\text { Technologies }\end{array}$ & $\begin{array}{l}\text { - Motivasi, } \\
\text { - Lingkungan Kerja } \\
\text { - Kepemimpinan } \\
\text { - Disiplin Kerja } \\
\text { - Kinerja Karyawan }\end{array}$ & $\begin{array}{l}\text { Hasil penelitian menunjukkan } \\
\text { bahwa kepemimpinan memiliki } \\
\text { hubungan yang signifikan } \\
\text { dengan disiplin kerja dengan } \\
\text { factor loading sebesar } 0,683 \\
\text { dan disiplin kerja memiliki } \\
\text { hubungan yang signifikan } \\
\text { dengan kinerja karyawan }\end{array}$ \\
\hline
\end{tabular}




\begin{tabular}{|c|c|c|c|c|}
\hline No. & Peneliti & Judul & Variabel Penelitian & Hasil Penelitian \\
\hline & & Lestary Jakarta & & $\begin{array}{l}\text { dengan factor loading sebesar } \\
0,833 \text {. Sedangkan hubungan } \\
\text { antara motivasi dengan disiplin } \\
\text { kerja, lingkungan kerja dengan } \\
\text { disiplin kerja, motivasi dengan } \\
\text { kinerja karyawan, dan } \\
\text { kepemimpinan dengan kinerja } \\
\text { karyawan, tidak memiliki } \\
\text { hubungan yang signifikan. }\end{array}$ \\
\hline 8 & $\begin{array}{l}\text { Rahim, at.all } \\
\text { (2017) }\end{array}$ & $\begin{array}{l}\text { Pengaruh } \\
\text { Lingkungan Kerja } \\
\text { dan Kompetensi } \\
\text { Terhadap Motivasi } \\
\text { Kerja r Serta } \\
\text { Dampaknya } \\
\text { Terhadap Kinerja } \\
\text { Pegawai Pada } \\
\text { Dinas Pendidikan } \\
\text { Kabupaten Tanjung } \\
\text { Jabung Timur }\end{array}$ & $\begin{array}{l}\text { - Lingkungan Kerja } \\
\text { - Kompetensi } \\
\text { - Motivasi Kerja } \\
\text { Serta } \\
\text { - Kinerja Pegawai }\end{array}$ & $\begin{array}{l}\text { Berdasarkan hasil penelitian } \\
\text { diketahui lingkungan kerja, } \\
\text { kompetensi, motivasi dan } \\
\text { kinerja pegawai di Dinas } \\
\text { Pendidikan Kabupaten Tanjung } \\
\text { Jabung dalam kondisi cukup } \\
\text { baik; lingkungan kerja dan } \\
\text { kompetensi yang berpengaruh } \\
\text { positif dan signifikan terhadap } \\
\text { motivasi kerja baik secara } \\
\text { parsial maupun simultan; } \\
\text { lingkungan kerja dan } \\
\text { kompetensi pengaruh positif } \\
\text { dan signifikan terhadap kinerja } \\
\text { pegawai baik secara parsial } \\
\text { maupun simultan; motivasi } \\
\text { kerja berpengaruh terhadap } \\
\text { kinerja karyawan; } \\
\text { lingkungan kan } \\
\text { kompetensi bersama melalui } \\
\text { motivasi mempengaruhi kinerja } \\
\text { karyawan langsung dan tidak } \\
\text { langsung terhadap Dinas } \\
\text { Pendidikan Kabupaten Tanjung } \\
\text { Jabung. }\end{array}$ \\
\hline 9 & $\begin{array}{l}\text { Arninda } \\
\text { (2017) }\end{array}$ & $\begin{array}{l}\text { Analisis } r \text { Pengaruh } \\
\text { Keamanan Kerja } \\
\text { Dan Kompensasi } \\
\text { Terhadap } \\
\text { Keinginan } \\
\text { Berpindah Serta } \\
\text { Dampaknya Pada } \\
\text { Kinerja Karyawan } \\
\text { Kontrak } \quad \text { Studi } \\
\text { Pada PT. Kapuas } \\
\text { Media Utama Press }\end{array}$ & $\begin{array}{l}\text { - Keamanan Kerja } \\
\text { - Kompensasi } \\
\text { - Keinginan } \\
\text { Berpindah } \\
\text { - Kinerja Karyawan } \\
\text { Kontrak }\end{array}$ & $\begin{array}{l}\text { Hasil penelitian menunjukkan } \\
\text { bahwa persentase pengaruh } \\
\text { variabel keamanan kerja dan } \\
\text { kompensasi terhadap variabel } \\
\text { keinginan berpindah adalah } \\
\text { sebesar } 86,1 \% \text {, sedangkan } \\
\text { sisanya sebesar } 13,9 \% \\
\text { dipengaruhi oleh variabel lain } \\
\text { yang tidak ada dalam model } \\
\text { penelitian ini dan persentase } \\
\text { pengaruh variabel keamanan }\end{array}$ \\
\hline
\end{tabular}




\begin{tabular}{|l|l|l|l|l|}
\hline No. & Peneliti & \multicolumn{1}{|c|}{ Judul } & Variabel Penelitian & \multicolumn{2}{|c|}{ Hasil Penelitian } \\
\hline & & Kalimantan Barat) & & kerja, kompensasi dan \\
& & & keinginan berpindah terhadap \\
& & & variabel kinerja karyawan \\
& & & adalah sebesar 84,9\%, \\
& & & sedangkan sisanya sebesar \\
& & & \\
& & & lain yang tidak ada dalam model \\
& & & penelitian ini. \\
\hline
\end{tabular}

\section{Kerangka Pemikiran Konseptual}

Kerangka pikiran teoritis yang di kembangkan pada penelitian ini adalah mengacu dari telaah dan referensi dari berbagai buku pustaka yang telah dilakukan. Berdasarkan hasil telaah pada penelitian ini terdapat empat variabel, yaitu kompensasi, lingkungan kerja, motivasi kerja dan kinerja pegawai. Dalam penelitian ini variabel kompensasi dan lingkungan kerja merupakan variabel eksogen, sedangkan variabel motivasi pegawai merupakan variabel antara (intervening) dan variabel kinerja pegawai merupakan variabel endogen. Untuk jelasnya dapat dilihat dalam skema kerangka penelitian berikut ini:

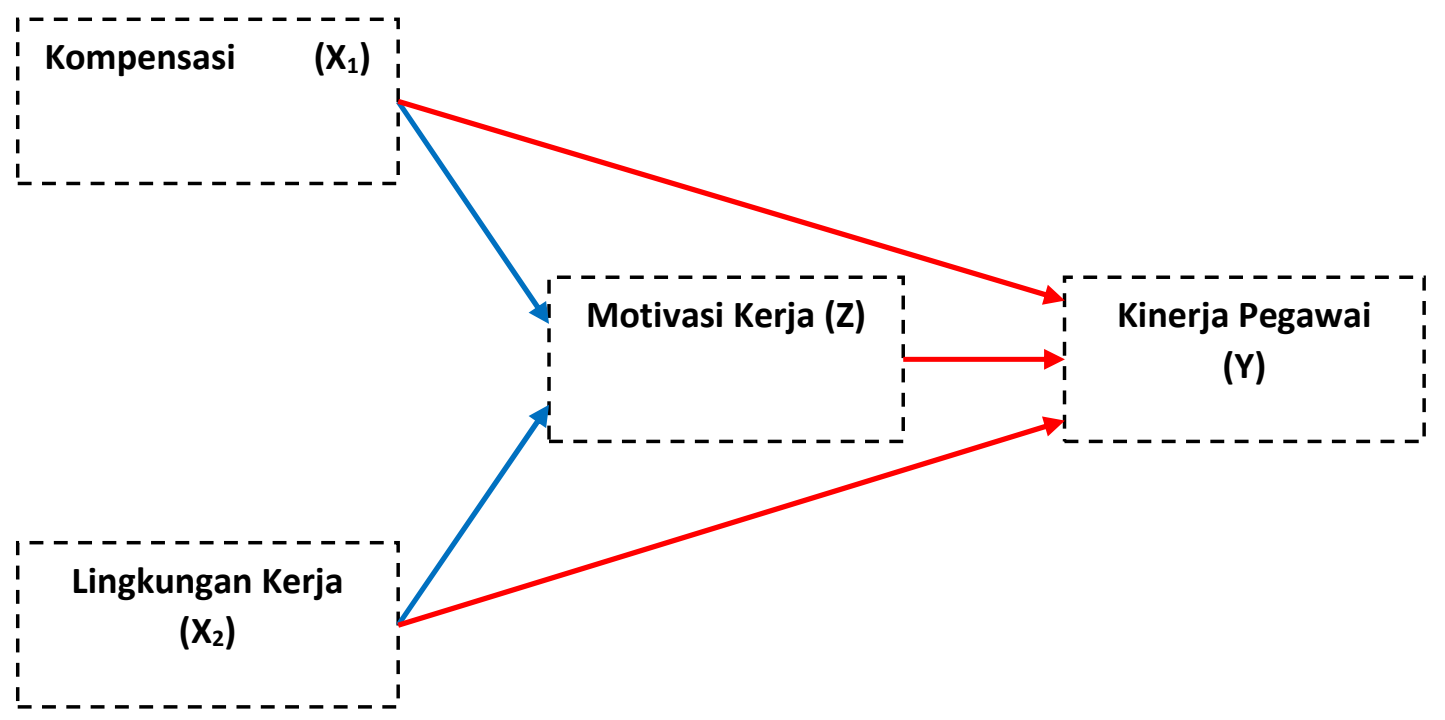

Gambar 2 Kerangka Konseptual 


\section{METODE PENELITIAN}

\section{Desain Penelitian}

Penelitian ini merupakan penelitian kuantitatif, di mana dalam penelitian ini terdiri atas empat variabel, yaitu kompensasi, lingkungan kerja sebagai variabel bebas (independent), motivasi sebagai variabel intervening, dan kinerja sebagai variabel terikat (dependent).

\section{Teknik Pengambilan Data}

Data penelitian diperoleh dengan menyebar kuesioner pada 248 Karyawan dari total populasi sebanyak 650 (Rumus Slovin) dengan pendekatan Purposive sampling

\section{Definisi Operasional}

Untuk memberikan gambaran yang lebih jelas tentang variabel penelitian, maka disajikan tabel sebagai berikut:

\section{Tabel 2}

Definisi Operasional Variabel

\begin{tabular}{|c|c|c|c|c|}
\hline Variabel & Definisi & Sub Variabel & Indikator & $\begin{array}{l}\text { Skala } \\
\text { Ukuran }\end{array}$ \\
\hline \multirow[b]{2}{*}{ Eksogenous } & \multirow{2}{*}{$\begin{array}{l}\text { Kompensasi }\left(\mathbf{X}_{1}\right) \\
\text { Merupakan suatu bentuk biaya } \\
\text { yang harus dikeluarkan oleh } \\
\text { perusahaan dengan harapan bahwa } \\
\text { perusahaan akan memperoleh } \\
\text { imbalan dalam bentuk prestasi } \\
\text { kerja dari karyawan. } \\
\text { (Sofyandi, 2008:159) }\end{array}$} & $\begin{array}{l}\text { Kompensasi } \\
\text { finansial }\left(\mathrm{X}_{11}\right)\end{array}$ & $\begin{array}{ll}\text { - } & \text { Gaji / upah }\left(\mathrm{X}_{11 \mathrm{a}}\right) \\
\text { - } & \text { Insentif }\left(\mathrm{X}_{11 \mathrm{~b}}\right) \\
\text { - } & \text { Tunjangan }\left(\mathrm{X}_{11 \mathrm{c}}\right) \\
\text { - } & \text { Bonus }\left(\mathrm{X}_{11 \mathrm{~d}}\right) \\
\end{array}$ & \multirow[b]{2}{*}{$\begin{array}{l}\text { Skala } \\
\text { Likert 1- } \\
5\end{array}$} \\
\hline & & $\begin{array}{l}\text { Kompensasi non } \\
\text { finansial }\left(\mathrm{X}_{12}\right)\end{array}$ & $\begin{array}{ll}- & \text { Berhubungan dengan } \\
& \text { pekerjaan }\left(\mathrm{X}_{12 \mathrm{a}}\right) \\
\text { - } & \text { Berhubungan dengan } \\
& \text { lingkungan kerja }\left(\mathrm{X}_{12 \mathrm{~b}}\right) \\
\text { - } & \text { Berhubungan dengan } \\
& \text { Fasilitas }\left(\mathrm{X}_{12 \mathrm{c}}\right) \\
\end{array}$ & \\
\hline \multirow[b]{2}{*}{ Eksogenous } & \multirow[b]{2}{*}{$\begin{array}{l}\text { Lingkungan Kerja }\left(\mathbf{X}_{2}\right) \\
\text { Merupakan keseluruhan alat } \\
\text { perkakas dan bahan yang dihadapi } \\
\text { lingkungan sekitarnya dimana } \\
\text { seseorang bekerja, metode } \\
\text { kerjanya, serta pengaturan } \\
\text { kerjanya baik sebagai } \\
\text { perseorangan maupun sebagai } \\
\text { kelompok. } \\
\text { (Sedarmayanti, 2012:21) }\end{array}$} & $\begin{array}{l}\text { Lingkungan Fisik } \\
\left(\mathrm{X}_{21}\right)\end{array}$ & $\begin{array}{ll}- & \text { Hubungan pribadi }\left(\mathrm{X}_{21 \mathrm{a}}\right) \\
\text { - } & \text { Supervisi }\left(\mathrm{X}_{21 \mathrm{~b}}\right) \\
\end{array}$ & \\
\hline & & $\begin{array}{l}\text { Lingkungan Non } \\
\text { Fisik }\left(\mathrm{X}_{22}\right)\end{array}$ & $\begin{array}{ll}\text { - } & \text { Kebersihan }\left(X_{22 \mathrm{a}}\right) \\
\text { - } & \text { Suara }\left(\mathrm{X}_{22 \mathrm{~b}}\right) \\
\text { - } & \text { Pencahayaan }\left(\mathrm{X}_{22 \mathrm{c}}\right) \\
\text { - } & \text { Udara }\left(\mathrm{X}_{22 \mathrm{~d}}\right) \\
\text { - } & \text { Keamanan }\left(\mathrm{X}_{22 \mathrm{e}}\right)\end{array}$ & $\begin{array}{c}\text { Skala } \\
\text { Likert 1- } \\
\quad 5\end{array}$ \\
\hline
\end{tabular}




\begin{tabular}{|c|c|c|c|c|}
\hline Variabel & Definisi & Sub Variabel & Indikator & $\begin{array}{l}\text { Skala } \\
\text { Ukuran }\end{array}$ \\
\hline \multirow{3}{*}{ Endogenous } & \multirow{3}{*}{$\begin{array}{l}\text { Motivasi Kerja (Z) } \\
\text { Merupakan sebuah proses } \\
\text { psikologi dimana rasa } \\
\text { ketidakpuasan pada kebutuhan } \\
\text { ataupun keinginan yang ada } \\
\text { sehingga berusaha untuk } \\
\text { mencapai suatu tujuan yang } \\
\text { diinginkan. } \\
\text { (Fred Luthans, 2011:422) }\end{array}$} & 1) Promosi & $\begin{array}{ll}\text { - } & \text { Tanggung jawab yang lebih } \\
\text { berat } \\
\text { - } \\
\text { - } \\
\text { Tartabat atau status } \\
\text { upah atau gaji. }\end{array}$ & \multirow{3}{*}{$\begin{array}{l}\text { Skala } \\
\text { Likert 1- } \\
\quad 5\end{array}$} \\
\hline & & 2) Prestasi Kerja & $\begin{array}{ll}\text { - } & \text { Mampu menyelesaikan } \\
& \text { pekerjaan } \\
\text { - } & \text { Promosi Jabatan } \\
\text { - } & \text { Pengembangan karir } \\
\end{array}$ & \\
\hline & & 3) Penghargaan & $\begin{array}{ll}\text { - } & \text { Penghargaan atas } \\
\text { prestasinya } \\
\text { - } & \text { Pengakuan atas keahlian } \\
\end{array}$ & \\
\hline \multirow{5}{*}{ Endogenous } & \multirow{5}{*}{$\begin{array}{l}\text { Kinerja (Y) } \\
\text { Merupakan hasil kerja dilihat } \\
\text { dari aspek kualitas, kuantitas, } \\
\text { waktu kerja, dan kerja sama } \\
\text { untuk mencai tujuan yang sudah } \\
\text { di tetapkan oleh organisasi. } \\
\text { (Edy Sutrisno, 2010:172) }\end{array}$} & Kualitas $\left(\mathrm{Y}_{1}\right)$ & Keterampilan $\left(\mathrm{Y}_{1 \mathrm{a}}\right)$ & \multirow{5}{*}{$\begin{array}{l}\text { Skala } \\
\text { Likert 1- } \\
\quad 5\end{array}$} \\
\hline & & & Kemampuan karyawan $\left(\mathrm{Y}_{1 \mathrm{~b}}\right)$ & \\
\hline & & Kuantitas $\left(\mathrm{Y}_{2}\right)$ & $\begin{array}{l}\text { Jumlah aktivitas yang } \\
\text { diselesaikan }\left(\mathrm{Y}_{2 \mathrm{a}}\right)\end{array}$ & \\
\hline & & $\begin{array}{l}\text { Ketepatan waktu } \\
\left(\mathrm{Y}_{3}\right)\end{array}$ & $\begin{array}{l}\text { Tingkat aktivitas yang } \\
\text { diselesaikan tepat waktu }\left(\mathrm{Y}_{3 \mathrm{a}}\right)\end{array}$ & \\
\hline & & $\begin{array}{l}\text { Komitmen Kerja } \\
\left(\mathrm{Y}_{4}\right)\end{array}$ & $\begin{array}{l}\text { Tingkat komitmen kerja } \\
\text { karyawan di kantor }\left(\mathrm{Y}_{4 \mathrm{a}}\right)\end{array}$ & \\
\hline
\end{tabular}

\section{Teknik Analisis Data}

Teknik pengolahan data yang digunakan dalam penelitian ini menggunakan Structural Equation Modeling (SEM) yang memiliki kemampuan menguji suatu rangkaian hubungan yang kompleks. Software yang digunakan adalah Lisrel 8.8 dan software SPSS versi 21.0

\section{HASIL DAN PEMBAHASAN}

\section{Uji Kecocokan Keseluruhan Model dan Respesifikasi}

Semua item pernyataan mengenai kompensasi sebanyak 7 pernyataan adalah valid karena menunjukkan hasil $r_{\text {hitung }}$ lebih besar dari $r_{\text {tabel}}$, artinya semua butir pernyatan dapat digunakan sebagai instrument penelitian. Indikator lingkungan kerja sebanyak 7 pernyataan adalah valid, variable lain juga mememnuhi uji Validitas dan relaibilitas.

Setelah lolos pengujian validitas dan reliabilitas dengan model CFA, maka tahap selanjutnya adalah menganalisis kecocokan data dengan model secara keseluruhan atau dalam LISREL. Uji keseluruhan model berkaitan dengan analisis terhadap Goodness ofFit (GOF) statistik yang dihasilkan oleh program LISREL. 
Dari data printed output yang dihasilkan estimasi pengukuran 2 nd CFA pada program LISREL, analisis kecocokan keseluruhan model dapat dilihat dari angka statistik sebagai berikut :

a) Nilai Chi-square yaitu 851.11 dan $\mathrm{p}=0.0000<0.05$. Hasil tersebut menunjukkan bahwa kecocokan kurang baik karena syarat model yang baik yaitu Chi-square dan $\mathrm{p}$ value $>0.05$ tidak terpenuhi.

b) Nilai RMSEA yaitu 0.065 yang berarti kecocokan model adalah diterima atau marginal fit. Nilai RMSEA $\leq 0.05$ menandakan close fit, sedangkan $0.05<$ RMSEA $\leq$ 0.05 menunjukkan good fit, sedangkan jika nilai RMSEA antara 0.059 sampai 0.071 adalah marginal fit dan nilai RMSEA > 0.05 menunjukkan poor fit. (Brown dan Cudeck 1993 dalam Setyo Hari Wijanto, 2015).

c) Selanjutnya, NFI $=0.93$; nilai kecocokan model pada NFI dikategorikan ke dalam poor fit Nilai $0.90 \leq \mathrm{NFI}<0.91$ pada NFI dikatakan marginal fit sedangkan nilai 0.90 $\leq \mathrm{NFI} \leq 1.00$ kecocokan model tersebut disebut sebagai good fit .

d) Nilai CFI pada penelitian ini adalah 0.96; maka kecocokan seluruh model adalah marginal fit. Hal tersebut didasarkan pada nilai CFI berkisar antara 0 sampai 1. Jika nilai $0.90 \leq \mathrm{CFI} \leq 1.00$ sering disebut sebagai good fit, sehingga jika $0.97 \geq \mathrm{CFI} 0.95$ kecocokan model tersebut dikatakan marginal fit.

e) Nilai GFI yaitu sebesar 0.82 sehingga kecocokan model berada pada marginal fit. Nilai kecocokan model yang baik atau good fit untuk parameter GFI adalah $0.90 \leq$ GFI $\leq 1.00$ serta parameter $0.87 \leq \mathrm{CFI}<0.90$ GFI dapat dikatakan marginal fit.

f) Nilai AGFI adalah 0.79 yang berarti tidak jauh berbeda dengan kecocokan model pada GFI yaitu marginal fit. Nilai kecocokan model yang baik untuk parameter AGFI adalah $0.90 \leq$ AGFI $\leq 1.00$ serta parameter $0.90 \leq$ CFI $<0.90$ GFI dapat dikatakan marginal fit.

Tabel 3 berikut menyimpulkan hasil uji kecocokan keseluruhan model. Dari pembahasan yang telah dilakukan di atas, ada 2 (dua) ukuran GoF yang dikatakan kurang baik atau poor fit, serta ada 4 (empat) ukuran GoF yang menunjukkan kecocokan marginal fit. Sehingga, dapat disimpulkan bahwa kecocokan model pada penelitian ini ada pada kategori marginal fit. 
Tabel 3

Goodness of Fit Statistics

\begin{tabular}{|c|c|c|c|c|}
\hline $\begin{array}{c}\text { Fit } \\
\text { Measure }\end{array}$ & Good Fit & Marginal fit & Hasil & Kesimpulan \\
\hline p-value & $0.05<\mathrm{p} \leq 1.00$ & $\begin{array}{c}0.000<\mathrm{p} \leq \\
0.05\end{array}$ & 0.000 & Poor fit \\
\hline RMSEA & $\begin{array}{c}0.05<\mathrm{RMSEA} \\
\leq 0.08\end{array}$ & $\begin{array}{c}0.05 \leq \\
\text { RMSEA } \leq \\
0.10\end{array}$ & 0.065 & Marginal fit \\
\hline NFI & $\begin{array}{c}0.90 \leq \mathrm{NFI} \leq \\
1.00\end{array}$ & $\begin{array}{c}0.90 \leq \mathrm{NFI}< \\
0.90\end{array}$ & 0.93 & Good fit \\
\hline CFI & $\begin{array}{c}0.90 \leq \mathrm{CFI} \leq \\
1.00\end{array}$ & $\begin{array}{c}0.90 \leq \mathrm{CFI}< \\
0.90\end{array}$ & 0.96 & Good fit \\
\hline GFI & $\begin{array}{c}0.90 \leq \mathrm{GFI} \leq \\
1.00\end{array}$ & $\begin{array}{c}0.90 \leq \mathrm{CFI}< \\
0.90\end{array}$ & 0.82 & Marginal fit \\
\hline AGFI & $\begin{array}{c}0.90 \leq \mathrm{AGFI} \leq \\
1.00\end{array}$ & $\begin{array}{c}0.90 \leq \mathrm{AGFI}< \\
0.90\end{array}$ & 0.79 & Marginal fit \\
\hline
\end{tabular}

Sumber: Output LISREL 8.8 Hasil Olahan Penelitian, 2017

\section{Analisis Model Struktural}

Setelah mengenalisis hasil dari goodness of fit model penelitian, analisis berikutnya yang dilakukan adalah dengan melakukan analisis hubungan kausal pada model. Pengujian statistik untuk hubungan kausal model structural ini dilakukan dengan tingkat signifikansi $5 \%$ sehingga nilai kritis dari $t$-value adalah \pm 1.96 . Hasil estimasi semua hubungan kausal penelitian bisa dilihat pada hasil output LISREL 8.8 berikut ini: 


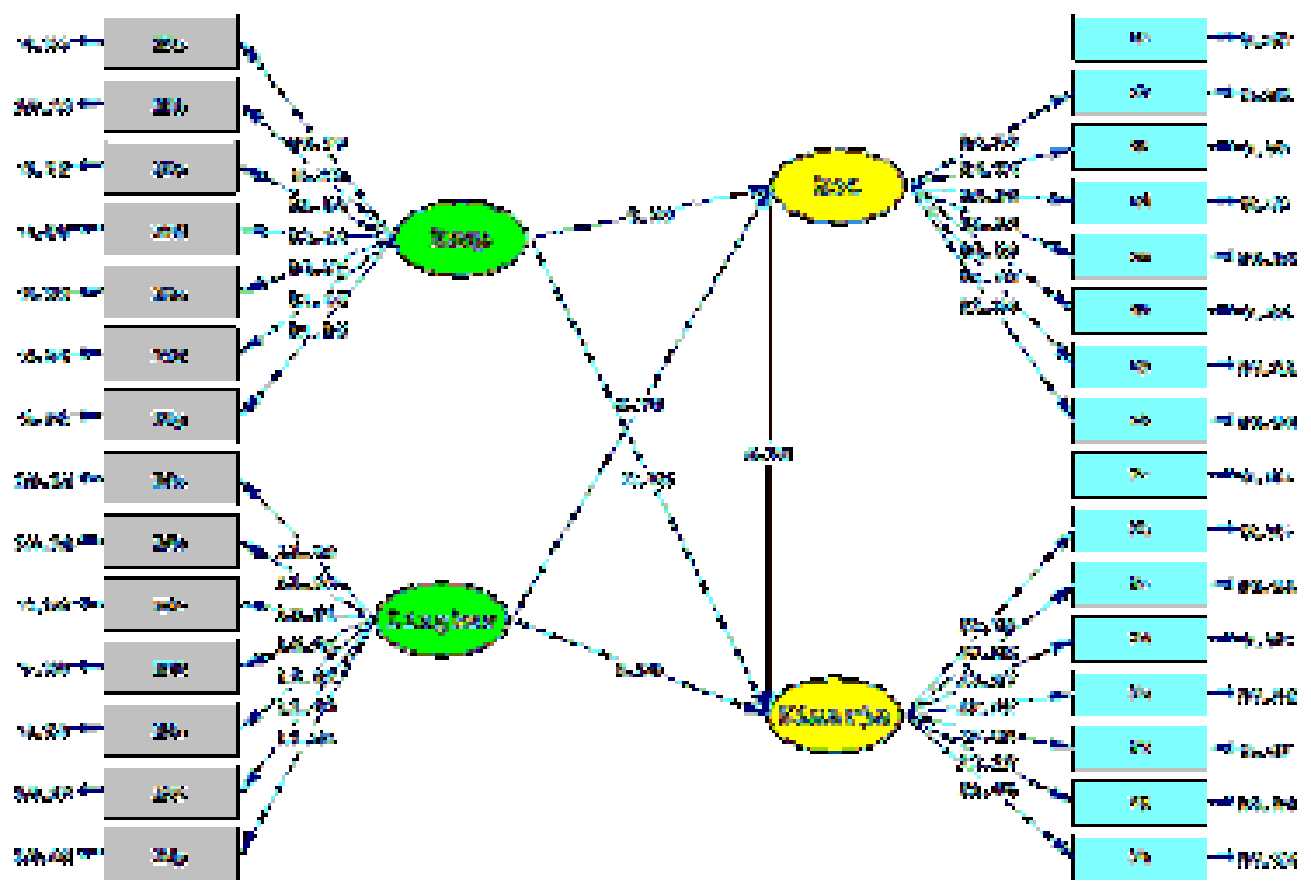

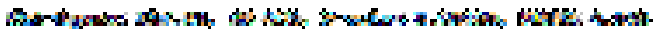

Sumber: Output LISREL 8.8 Hasil Olahan Peneliti, 2017

\section{Gambar 3 Full Model Model Struktural (t-value)}

Dari hasil output LISREL 8.8 untuk persamaan hubungan kausal di atas, dapat dilihat bahwa dari persamaan kausal di atas, $t$-value yang besar nilai absolutnya $>1.96$ memiliki arti bahwa koefisien lintasan tersebut adalah signifikan. Berikut ini adalah tabel ringkasan dari $t$-value dan koefisien pada model struktural:

Tabel 4 T-value dan Standardized Estimate Persamaan Struktural

\begin{tabular}{|l|c|c|}
\hline \multicolumn{1}{|c|}{ Variabel } & $\begin{array}{c}\text { Standardized } \\
\text { Estimate }(\boldsymbol{\beta})\end{array}$ & Nilai t \\
\hline Kompensasi terhadap Kinerja & 0.18 & 2.36 \\
\hline Kompensasi terhadap Motivasi & 0.37 & 4.59 \\
\hline Lingkungan kerja terhadap Kinerja & 0.33 & 4.50 \\
\hline Lingkungan kerja terhadap Motivasi & 0.21 & 2.74 \\
\hline Motivasi terhadap Kinerja & 0.27 & 3.78 \\
\hline
\end{tabular}

Sumber: Output LISREL 8.8 Hasil Olahan Peneliti, 2017

Dari tabel di atas, dapat dilihat bahwa terdapat variabel kompensasi terhadap kinerja berpengaruh tidak signifikan, kompensasi terhadap motivasi berpengaruh tidak signifikan, lingkungan kerja terhadap kinerja berpengaruh tidak signifikan, lingkungan 
kerja terhadap motivasi berpengaruh tidak signifikan, dan motivasi terhadap kinerja berpengaruh tidak signifikan. Interpretasi dari koefisien lintasan yang tersebut akan dijelaskan lebih lanjut pada bagian pengujian hipotesis.

\section{Pengujian Hipotesis}

Berdasarkan kerangka konseptual penelitian yang telah dikemukakan sebelumnya, penelitian ini memiliki beberapa hipotesis berupa $\mathrm{H}_{\mathrm{o}}$ dan $\mathrm{H}_{\mathrm{a}}$ dari masingmasing variabel. Di mana $\mathrm{H}_{\mathrm{o}}$ merupakan asumsi hipotesis yang tidak memiliki pengaruh sedangkan $\mathrm{H}_{\mathrm{a}}$ merupakan asumsi hipotesis yang memiliki pengaruh.

Untuk menguji hipotesis tersebut dilakukan uji statistik dengan perhitungan Structural Equation Modelling (SEM) Analysis sebagai analisis kuantitatif. Menurut Augisty (2006) "uji statistik t pada dasarnya menunjukkan seberapa jauh pengaruh satu variabel penjelas/eksogen secara individual dalam menerangkan variabel endogen". Nilai $t$ value dalam SEM dapat dilihat pada gambar berikut :

Uji hipotesis dinyatakan $\mathrm{H}_{\mathrm{o}}$ ditolak atau variabel tersebut berpengaruh apabila $t$ value $>1.96$ pada $\alpha=0.05$. Berikut penjelasan mengenai keterkaitan antara masing-masing variabel dalam penelitian ini.

1. Pengaruh Kompensasi terhadap Kinerja

Berdasarkan tabel 4 di atas, terlihat bahwa hasil t-value adalah 2.36. Jadi, dapat disimpulkan bahwa Kompensasi berpengaruh terhadap Kinerja karyawan pada PT. Petroil Indonesia karena hasil t-value $>1.96$.

2. Pengaruh Kompensasi terhadap Motivasi

Berdasarkan tabel 4 di atas, terlihat bahwa hasil t-value adalah 4.59. Jadi, dapat disimpulkan bahwa Kompensasi berpengaruh terhadap motivasi karyawan pada PT. Petroil Indonesia karena hasil $t$-value $>1.96$.

3. Pengaruh Lingkungan Kerja terhadap Kinerja

Berdasarkan tabel 4 di atas, terlihat bahwa hasil t-value adalah 4.50. Jadi, dapat disimpulkan bahwa Lingkungan kerja berpengaruh terhadap Kinerja karyawan pada PT. Petroil Indonesia karena hasil $t$-value $>1.96$.

4. Pengaruh Lingkungan Kerja terhadap Motivasi 
Berdasarkan tabel 4 di atas, terlihat bahwa hasil t-value adalah 2.74. Jadi, dapat disimpulkan bahwa lingkungan kerja berpengaruh terhadap motivasi karyawan pada PT. Petroil Indonesia karena hasil $t$-value $>-1.96$.

\section{Pembahasan}

Penelitian ini dapat melihat pengaruh langsung dan tidak langsung. Pengaruh langsung adalah pengaruh yang terjadi antara 2 buah variabel ketika sebuah panah menghubungkan keduanya. Sedangkan pengaruh tidak langsung adalah pengaruh yang terjadi diantara 2 variabel tidak ada panah langsung antara kedua variabel tersebut melainkan melalui satu atau lebih variabel lain sesuai lintasan yang ada. Pengujian langsung yaitu pengaruh kompensasi terhadap kinerja, pengaruh lingkungan kerja terhadap kinerja dan pengaruh motivasi terhadap kinerja. Pengujian tidak langsung adalah melibatkan variabel intervening yaitu pengaruh kompensasi terhadap kinerja melalui motivasi, serta pengaruh lingkungan kerja terhadap kinerja melalui motivasi.

Untuk melihat pengaruh langsung atau tidak langsung atas variabel kompensasi $\left(\mathrm{X}_{1}\right)$ dan lingkungan kerja $\left(\mathrm{X}_{2}\right)$ terhadap kinerja $(\mathrm{Y})$ serta dampaknya pada motivasi $(\mathrm{Z})$ dapat dilihat pada tabel 5 berikut ini :

Tabel 5 Pengaruh Langsung dan Tidak Langsung $X_{1}, X_{2}$ terhadap Y dan dampaknya terhadap $Z$ serta Pengaruh Total

\begin{tabular}{|l|l|l|l|}
\hline Pengaruh Variabel & $\begin{array}{l}\text { Pengaruh } \\
\text { Langsung }\end{array}$ & $\begin{array}{l}\text { Pengaruh Tidak } \\
\text { Langsung }\end{array}$ & Total \\
\hline Kompensasi terhadap Kinerja & 0.18 & 0 & 0.18 \\
\hline $\begin{array}{l}\text { Kompensasi terhadap } \\
\text { Motivasi }\end{array}$ & $\begin{array}{l}\text { Melalui Kinerja } \\
0.37 \times 0.27\end{array}$ & 0.10 \\
\hline Pengaruh total Kompensasi terhadap Motivasi & 0.28 \\
\hline $\begin{array}{l}\text { Lingkungan kerja terhadap } \\
\text { Kinerja }\end{array}$ & 0.33 & 0 & 0.33 \\
\hline $\begin{array}{l}\text { Lingkungan kerja terhadap } \\
\text { Motivasi }\end{array}$ & $\begin{array}{l}\text { Melalui Kinerja } \\
0.21+0.27\end{array}$ & 0.06 \\
\hline Pengaruh total Kompensasi terhadap Motivasi & 0.39 \\
\hline Motivasi terhadap Kinerja & 0.27 & 0.27 \\
\hline Jumlah & 0 & $\mathbf{0 . 9 4}$ \\
\hline
\end{tabular}


Berdasarkan tabel di atas, dijelaskan bahwa pengaruh langsung kompensasi terhadap kinerja adalah 0.33 (33\%) dan pengaruh tidak langsung melalui motivasi adalah 0.10 (90\%). Total pengaruh kompensasi terhadap kinerja adalah $0.28(28 \%)$.

Pengaruh langsung kompensasi terhadap kinerja adalah 0.33 (33\%) dan pengaruh tidak langsung melalui motivasi adalah $0.06(6 \%)$. Total pengaruh kompensasi terhadap kinerja adalah $0.39(39 \%)$.

Pada hipotesis $\mathrm{H}_{1}$, diambil dua hipotesis yaitu Hol dan Ha1. Berdasarkan hasil uji hipotesis pada tingkat keyakinan 95\% dengan mempertimbangkan t-value $>1.96$, dinyatakan bahwa $\mathrm{Ho}_{1}$ ditolak karena t-value nya sebesar 2.36. Penolakan $\mathrm{Ho}_{1}$ tersebut menyatakan bahwa terdapat pengaruh antara kompensasi dengan kinerja pada PT. Petroil Indonesia.

Untuk dapat menghasilkan kinerja baik, maka perusahaan harus menyesuaikan pekerjaan dengan besarnya bonus yang diberikan disesuaikan dengan besarnya prestasi kerja yang dilakukan oleh karyawan. Dari hasil uji hipotesis ini terlihat bahwa kompensasi berpengaruh terhadap kinerja pada PT. Petroil Indonesia.

Hasil penelitian ini sejalan dengan penelitian yang dilakukan oleh Pane, at.all (2009) mengatakan bahwa kompensasi berpengaruh terhadap kinerja karyawan pada Kantor Telkom Divre IV di Semarang.

Kemudian, hipotesis $\mathrm{H}_{2}$ juga ditarik menjadi $\mathrm{Ho} 2$ dan $\mathrm{Ha}_{2}$. Hipotesis $\mathrm{Ha}_{2}$ terbukti diterima karena $t$-value nya sebesar 4.50 (tingkat kepercayaan 95\%) atau $t$-value $<1.96$ yang berarti tidak terdapat pengaruh antara variabel lingkungan kerja dengan kinerja.

Untuk menghasilkan kinerja yang sesuai dengan keinginan perusahaan, maka perusahaan harus memperhatikan bahwa suara yang bising dapat mengganggu kosentrasi dalam bekerja. Dari hasil uji hipotesis ini terlihat bahwa lingkungan kerja memiliki pengaruh terhadap kinerja karyawan pada PT. Petroil Indonesia.

Hasil penelitian ini sejalan dengan penelitian yang dilakukan oleh Juliningrum, at.all, (2011) menyatakan bahwa kompensasi mempunyai pengaruh terhadap motivasi kerja pegawai PTIIK UB”.

Selanjutnya, hipotesis $\mathrm{H}_{3}$ memiliki t-value sebesar 4.59 (tingkat kepercayaan 95\%) atau Ho3 ditolak karena $t$-value $>1.96$. Hal tersebut menandakan bahwa adanya pengaruh antara kompensasi terhadap motivasi. 
Jika dikaitkan pada penelitian ini, peneliti dapat menyimpulkan bahwa apabila perusahaan dapat memenuhi hak-hak yang seharusnya diterima karyawan maka akan berdampak pada turunnya motivasi pegawai pada PT. Petroil Indonesia.

Hasil penelitian ini sejalan dengan penelitian yang dilakukan oleh Raja, (2017) menyatakan bahwa kompensasi mempunyai pengaruh positif terhadap motivasi kerja karyawan PT Asiana Technologies Lestary Jakarta. Manusia bekerja untuk dapat memenuhi kebutuhan hidupnya sehari-hari. Apabila perusahaan menginginkan karyawannya termotivasi dalam menjalankan pekerjaan, maka perusahaan harus berusaha untuk memenuhi kebutuhan para karyawannya. Kompensasi yang diberikan kepada pegawai sangat berpengaruh pada motivasi kerja karena berbagai macam bentuk kompensasi tambahan berfungsi untuk memotivasi karyawan agar produktivitasnya lebih tinggi.

Kemudian, hipotesis $\mathrm{H}_{4}$ memiliki t-value sebesar 2.74 (tingkat kepercayaan 95\%) atau Ho4 ditolak karena $t$-value $>1$ 1.96. Hal tersebut menandakan bahwa adanya pengaruh antara lingkungan kerja terhadap motivasi.

Jika dikaitkan pada penelitian ini, peneliti dapat menyimpulkan bahwa apabila lingkungan kerja kurang mendukung maka akan berdampak pada turunnya motivasi pegawai pada PT. Petroil Indonesia.

Hal ini sesuai dengan penelitian yang dilakukan Sahilmi, at.all, (2014), menyatakan bahwa lingkungan kerja berpengaruh signifikan terhadap kinerja pegawai Kantor Kementerian Agama Kabupaten Aceh Barat Daya.

Hipotesis $\mathrm{H}_{5}$ juga dipecah menjadi Ho5 dan Ha5. Setelah dilakukan uji hipotesis, diperoleh $t$-value sebesar 3.78 (tingkat kepercayaan 95\%). Berdasarkan hasil tersebut maka $\mathrm{Ha}_{5}$ diterima yaitu adanya pengaruh negatif antara kinerja terhadap kinerja. Hasil $t$-vaue yang sangat baik tersebut menunjukkan bahwa korelasi yang muncul diantara variabel kinerja dan motivasi adalah kuat dan signifikan.

Hal ini sesuai dengan penelitian yang dilakukan Rahim, at.all (2017) menyatakan bahwa motivasi kerja berpengaruh terhadap kinerja karyawan kantor PT. (Persero) Telekomunikasi Indonesia, Tbk Wilayah Aceh. 


\section{SIMPULAN}

Berdasarkan hasil penelitian yang telah dikemukakan, baik melalui kajian pustaka, observasi maupun analisis data dengan menggunakan Structural Equation Model (SEM) dan dengan melihat nilai signifikan serta nilai critical ratio, diperoleh bukti empiris bahwa kompensasi dan lingkungan kerja berpengaruh terhadap kinerja melalui motivasi kerja Pada PT. Petroil Indonesia. Dari hasil pengujian hipotesis, diketahui :

1. Terdapat pengaruh antara kompensasi terhadap kinerja pada PT. Petroil Indonesia, hal ini berdasarkan pada tingkat keyakinan 95\% dengan mempertimbangkan $t$-value $>1.96$, dinyatakan bahwa Ho1 ditolak karena $t$ value nya adalah 2.36 .

2. Terdapat pengaruh antara variabel lingkungan kerja terhadap kinerja pada PT. Petroil Indonesia, hal ini berdasarkan pada tingkat keyakinan 95\% dengan mempertimbangkan $t$-value $>1.96$, dinyatakan bahwa $\mathrm{Ho}_{1}$ ditolak karena $t$ value nya adalah 4.50 .

3. Terdapat pengaruh antara kompensasi terhadap motivasi pada PT. Petroil Indonesia, hal ini berdasarkan pada tingkat keyakinan 95\% dengan mempertimbangkan $t$-value $>1.96$, dinyatakan bahwa Ho ${ }_{1}$ ditolak karena $t$ value nya adalah 4.59 .

4. Terdapat pengaruh antara lingkungan kerja terhadap motivasi pada

PT. Petroil Indonesia, hal ini berdasarkan pada tingkat keyakinan 95\% dengan mempertimbangkan $t$-value $>1.96$, dinyatakan bahwa $\mathrm{Ho}_{1}$ ditolak karena $t$ value nya adalah 2.74 .

5. Terdapat pengaruh antara motivasi terhadap kinerja pada PT. Petroil Indonesia, hal ini berdasarkan pada tingkat keyakinan 95\% dengan mempertimbangkan $t$-value $>1.96$, dinyatakan bahwa Ho ditolak karena $t$ value nya adalah 3.78 . 


\section{DAFTAR PUSTAKA}

Ardi, (2016), Pengaruh Disiplin Kerja, Promosi Jabatan dan Kompensasi Terhadap Kinerja Pegawai pada Dinas Kebudayaan Pariwisata Pemuda dan Olahraga Kabupaten Rembang, Program Studi Magister Manajemen, Sekolah Tinggi Ilmu Ekonomi Pariwisata Indonesia (STIEPARI) Semarang, E B BANK, Vol. 7, No. 2, Desember 2016, LP3M STIEBBANK, ISSN (online) : 2442 - 4439, ISSN (print) : $2087-1406$.

Arninda (2017), Analisis Pengaruh Keamanan Kerja Dan Kompensasi Terhadap

Keinginan Berpindah Serta Dampaknya Pada Kinerja Karyawan Kontrak (Studi Pada PT. Kapuas Media Utama Press Kalimantan Barat), Program Studi Magister Manajemen Fakultas Ekonomi dan Bisnis Universitas Tanjung Pura, Vol 1, No 4 (2017) > B2041142002.

Augusty, Ferdinand. (2006). Metode Penelitian Manajemen: Pedoman Penelitian untuk skripsi, Tesis dan Disertai Ilmu Manajemen. Semarang: Universitas Diponegoro.

Hasibuan, Malayu S.P.(2009). Manajemen: Dasar, Pengertian, dan Masalah. Edisi Revisi. Jakarta: Bumi Aksara.

Juliningrum, at.all, (2011), Pengaruh Kompensasi, Budaya Organisasi, terhadap Motivasi Kerja dan Kinerja Pegawai PTIIK UB, Program Pascasarjana Fakultas Ekonomi dan Bisnis Universitas Brawijaya.

Luthans, F. (2011).Organizational behavior (4ed). New York: McGraw-Hill

Pane, at.all (2009), Pengaruh Budaya Organisasi, Kepemimpinan Transformasional, dan

Kompensasi Terhadap Kinerja Karyawan (Studi pada Kantor Telkom Divre IV di Semarang), Program Pascasarjana Universitas Stikubank, Telaah Manajemen, ISSN : 1693-9727.

Pontoh (2013), Pengaruh Kompensasi dan Beban Kerja Terhadap Kepuasan Kerja Dan Dampaknya Pada Kinerja Pegawai Pada Badan Perencanaan Pembangunan Daerah Propinsi Sulawesi Tengah, Mahasiswa Program Studi Magister Manajemen Pascasarjana Universitas Tadulako, e-Jurnal Katalogis, Volume 2 Nomor 1, Januari 2014 hlm 101-113 ISSN: 2302-2019.

Pulungan at.all (2015), Pengaruh Kepuasan Kerja, Kompensasi dan Pelatihan Terhadap Motivasi Serta Dampaknya Pada Kinerja Karyawan Kantor PT. (Persero) 
Telekomunikasi Indonesia, Tbk Wilayah Aceh, Magister Manajemen Program Pascasarjana Universitas Syiah Kuala Banda Aceh, Jurnal Manajemen ISSN 2302-0199.

Rahim, at.all (2017), Pengaruh Lingkungan Kerja dan Kompetensi Terhadap Motivasi

Kerja Serta Dampaknya Terhadap Kinerja Pegawai Pada Dinas Pendidikan Kabupaten Tanjung Jabung Timur, Program Magister Manajemen FE UNBARI, J-MAS Vol.2 No.2, Oktober 2017.

Raja, (2015), Hubungan Motivasi, Lingkungan Kerja, Kepemimpinan, Disiplin Kerja, dan Kinerja Karyawan PT Asiana Technologies Lestary Jakarta, Program Studi Magister Teknik Sipil, Program Pascasarjana, Universitas Atma Jaya Yogyakarta.

Rivai, Veithzal dan Ella Sagala, (2013). Manajemen Sumber Daya Manusia untuk Perusahaan, Jakarta: Rajawali Pers

Sahilmi, at.all, (2014), Pengaruh Penggunaan Sistem Informasi dan Lingkungan Kerja Terhadap Motivasi Kerja Serta Dampaknya Pada Kinerja Pegawai Kantor Kementerian Agama Kabupaten Aceh Barat Daya”, Magister Manajemen Program Pascasarjana Universitas Syiah Kuala Banda Aceh, Jurnal Manajemen ISSN 23020199.

Samsudin, Sadili. (2010). Manajemen Sumber Daya Manusia. Bandung: Pustaka Setia

Schultz, D., \& Schultz, E. S. (2010). Psychology and work today (10 edition). New York: Pearson

Sedarmayanti. (2011). Manajemen Sumber Daya Manusia, Reformasi Birokrasi dan Manajemen Pegawai Negeri Sipil, (Cetakan Kelima). Bandung: $\quad$ PT Refika Aditama.

Sofyandi, Herman, (2008), Manajemen Sumber Daya Manusia, Edisi Pertama,Yogyakarta : Graha Ilmu.

Sutrisno, Edy. (2010). Manajemen Sumber Daya Manusia. Jakarta: Kencana Wirawan, (2015), Manajemen Sumber Daya Indonesia, Jakarta: PT. Raja Grafindo. 